DOI https://doi.org/10.18551/rjoas.2017-11.12

\title{
METHODICAL APPROACH TO ASSESSMENT OF THE ENTERPRISE ECONOMIC POTENTIAL
}

\author{
Levchenko T.A., Konvisarova E.V., Candidates of Economic Sciences \\ Vyatrovich D.E., Graduate student \\ Vladivostok State University of Economics and Service, Vladivostok, Russia \\ E-mail: tat_levchenko22@mail.ru
}

\begin{abstract}
Carrying out the activity in equal conditions, enterprises can achieve different results, as they have different levels of economic potentials. Assessment of the economic potential allows developing a complex understanding of all aspects of the organization for increasing its investment activity, competitiveness and effective functioning. Over the years, theoretical justification of the category of economic potential has not developed a common approach and a common methodology for its evaluation. This is due to the variety of the concept, its versatility and diversity of economists' opinions. The aim of the research was the development of universal methods for the assessment of the economic potential and it's testing on materials of fisheries enterprises.
\end{abstract}

\section{KEY WORDS}

Economic potential, assessment of economic potential, methodology, production, innovation potential, financial potential, labor potential, marketing potential.

The economic potential of the modern organization is a complex multi-level category to which a systematic approach should be applied. Analysis of the economic potential allows to form complex assessment of the current and future state of the organization from various positions, and conduct intra-industry and inter-industry comparison of organizations.

However, the use of the category of economic potential has a number of difficulties associated with the contradictions in the rendering of given concept and the absence of a single, accepted methodology of quantitative evaluation. The aim of the study, summarized in the article, was the development of universal methods of evaluation of the economic potential and it's testing on materials of fisheries organizations. Objectives of the study were: assessment of the theoretical approaches to the concept of economic potential, substantiation of its target, development of a model of formation and realization of the economic potential of the organization, validation of approaches and methods of evaluation to determine the current level and reserves for its increasing, which is especially important in modern conditions of dynamically changing external environment, the high level of competition in all spheres of economic activity.

The category of economic potential is known in Russian science for over 40 years. From A.N. Azrilian and O.A. Zhigunova [14, p. 23], O.Y. Vorozhbit [13, p. 54; 11, p. 11] to T.V. Krashennikova [5, p. 10] and Kovaleva V. V. [4, p. 98]. From the point of view of targets, the economic potential of the enterprise is rendered as related to resource or effective potential. According to the resource approach, the economic potential represents a volume of already accumulated resources. According to effective approach economic potential is the ability of the economic system of any level to achieve a certain result, which is based on available opportunities.

Number of modern scientists (I.E., Gvarliani, S.V. Klimchuk, G.G. Nadvornaya, M.S. Oborin) give a generalized definition of economic potential as "a certain set of economic resources, generated by the economic entity, with the goal of creating the targeted, economically effective results of activity" [7, p. 75].

The types distinguish the following potentials: innovative, productive, intellectual, human, financial, organizational, managerial, marketing, socio-economic, environmental and others [10, p. 52]. 
In our opinion, the economic potential of the organization is formed on the basis of its productive and innovative potential as well as on labor, financial and marketing ones, as, in our opinion, they characterized all aspects of the enterprise and take into account the relationship with the external environment. The realization of the economic potential of the organization contributes to its quality upgrading, the formation of a new vector of development and the achieving the target indicators [1, 12]. For effective implementation of the economic potential of the organization its assessment is required. It allows to identify the current (reached) level of economic potential and the reserves for increasing. It is especially important in modern conditions of dynamically changing external environment, the high level of competition in all spheres of economic activity. The above mentioned determined the development of methods of estimation of economic potential and their regular upgrading is also necessary. Such sciences-economists as O.A. Zhigunova [14], Yu.G. Kanyuka [2], V.V. Kovalev [4], A.P. Latkin [6], M.K. Starovoitov, P.A. Fomin [8], Yu.V. Timofeeva [9], T.G. Sheshukova, E.V. Colesen [10] and others, contributed to the development of methods for assessing of economic potential of the organization. The technique, proposed by them, is based, mainly, on the using of financial indicators to measure its various components, which are compared with the criterial values. Financial indicators are easy to calculate using accounting forms, which greatly simplifies the evaluation process.

However, the following shortcomings of the existing methods of evaluating the economic potential of the organization might be marked: insufficient using of internal data of organization, which are not reflected in the forms of accounting (financial) reports of organization; the lack of a system of indicators for assessment of the economic potential of the organization and the indicators, characterizing marketing activity and its effectiveness; the inability to account the peculiarities of the activities of organizations, which are members of integration associations, for example, clusters.

These shortcomings indicate the need for improvement of previously developed methods. In our opinion, the most appropriate assessment of the economic potential of the organization should be in four areas: productive and innovative, financial, labor and marketing.

1. Evaluation of the productive and innovative potential of the organization.

The sources of productive and innovative potential are multiple relationships and interactions between the elements of the organization as a productive system. In this regard, it is appropriate to include the following indicators in block for assessment of productive potential: the level of depreciation of fixed assets $\left(P_{1}\right)$, returns on assets $\left(P_{2}\right)$, capital-labor ratio $\left(P_{3}\right)$, the proportion of costs for Research and Advanced Development (RAD) in the total amount of expenses for production and its realization $\left(\mathrm{P}_{4}\right)$, the ratio of fundamentally new products in the total volume of sold products $\left(P_{5}\right)$, the ratio of improved production in total sales $\left(\mathrm{P}_{6}\right)$.

2. Evaluation of the financial potential of the organization.

The economic potential of the organization is formed by effectively combining different types of resources, including financial ones [3]. The financial potential is based on the use of both own and borrowed funds. For the selection of indicators, characterizing the level of financial potential, it is necessary to evaluate the relationship of the final financial results of the organization and the factors of efficiency and intensity of using its resources.

Our calculations suggest that there is a strong positively directed connection between the amount of the net profit of the company and the following ratios: equity ratio $\left(F_{1}\right)$, return on equity $\left(F_{2}\right)$, return on assets $\left(F_{3}\right)$ the ratio of economic security of company's own assets $\left(F_{4}\right)$, the equity ratio $\left(F_{5}\right)$ the ratio of current liquidity $\left(F_{6}\right)$, the ratio of quick liquidity $\left(F_{7}\right)$. These ratios should be used to assess the financial potential of the organization. Each of these indicators can have both positive and negative effects on the value of financial potential and, through it, on the magnitude of the economic potential of the organization.

\section{Assessment of personnel potential of the organization.}

Effective selection of personnel is indispensable prerequisite and prime cause of the high competitiveness of any organization. Qualitative characteristics of the personnel determine the completeness of using the resource potential, high level of profitability, the 
positive dynamics of the production processes, and hence, the level of economic potential of the organization.

We propose a set of indicators to assess human resource potential, including the following indicators: average age of employees $\left(\mathrm{K}_{1}\right)$, the coefficient of constant personnel composition $\left(\mathrm{K}_{2}\right)$, ratio of employees' turnover $\left(\mathrm{K}_{3}\right)$, return on labor $\left(\mathrm{K}_{4}\right)$, labor efficiency $\left(\mathrm{K}_{5}\right)$, and the ratio of average wage to minimum subsistence income in the region $\left(\mathrm{K}_{6}\right)$.

4. Assessment of the marketing potential of the organization.

Forming a high level of economic potential is associated with a systemic approach to the marketing complex, integration of the parts of marketing system in the company, as well as modern and reliable information support of marketing decisions. The obtaining a positive effect increases the efficiency of business activity in general.

The following unit of marketing indicators is proposed for assessment of marketing potential: the degree of market coverage $\left(M_{1}\right)$, the degree of potential using $\left(M_{2}\right)$, ROI $\left(M_{3}\right)$.

According to the authors, the evaluation of the magnitude of the economic potential, provides the calculation of the integral indicator by the formula (1):

$$
E P=\sum_{i=1}^{4} q_{i} \sum_{a=1}^{t} k_{a} \cdot p_{a}
$$

Where: EP - the economic potential of the organization; qi - coefficient of significance in the block of indicators ( used to assess the economic potential of industrial enterprise); $\mathrm{ka}$ - is a coefficient, indicating the direction of influence of the specific indicator from a particular block on the economic potential of industrial enterprise (can take values 1 or -1 depending on whether a particular indicator is within the standard (recommended) or dynamics values); $\mathrm{p}_{\mathrm{a}}$ - the coefficient of significance of individual indicator from determined block; $\mathrm{t}$ - the number of indicators in the block.

Table 1 - Calculation of the Economic Potential of PJSC "Dalryba"

\begin{tabular}{|c|c|c|c|}
\hline Indicator & Value & Recommended value & $\mathrm{k}_{\mathrm{a}} \cdot \mathrm{p}_{\mathrm{a}}$ \\
\hline $\mathrm{P}_{1}$ & 0,53 & $<0,5$ & $+0,17$ \\
\hline $\mathrm{P}_{2}$ & 12,02 & Positive dynamics & $-0,17$ \\
\hline $\mathrm{P}_{3}$ & 407,55 & Positive dynamics & $+0,17$ \\
\hline $\mathrm{P}_{4}$ & 0,0 & Positive dynamics & $-0,17$ \\
\hline $\mathrm{P}_{5}$ & 0,0 & 0,06 & $+0,17$ \\
\hline $\mathrm{P}_{6}$ & 0,10 & 0,10 & $+0,17$ \\
\hline $\mathrm{F}_{1}$ & 0,82 & $\geq 0,5$ & $+0,14$ \\
\hline $\mathrm{F}_{2}$ & 0,57 & $\geq 0,1$ & $+0,14$ \\
\hline $\mathrm{F}_{3}$ & 0,46 & $\geq 0,03$ & $+0,14$ \\
\hline $\mathrm{F}_{4}$ & 0,76 & $\geq 0,2$ & $+0,14$ \\
\hline $\mathrm{F}_{5}$ & 0,72 & $\geq 0,2$ & $+0,14$ \\
\hline $\mathrm{F}_{6}$ & 4,18 & $\geq 1,5$ & $+0,14$ \\
\hline $\mathrm{F}_{7}$ & 3,11 & $\geq 1$ & $+0,14$ \\
\hline $\mathrm{K}_{1}$ & 45 & $35-45$ & $+0,17$ \\
\hline $\mathrm{K}_{2}$ & 0,50 & $>0,9$ & $-0,17$ \\
\hline $\mathrm{K}_{3}$ & 0,49 & $<0,05$ & $-0,17$ \\
\hline $\mathrm{K}_{4}$ & 1063,79 & Positive dynamics & $+0,17$ \\
\hline$K_{5}$ & 4897,95 & Positive dynamics & $+0,17$ \\
\hline$K_{6}$ & 6,06 & $>3,8$ & $+0,17$ \\
\hline$M_{1}$ & 634,50 & Positive dynamics & $+0,33$ \\
\hline$M_{2}$ & 0,01 & Positive dynamics & $+0,33$ \\
\hline$M_{3}$ & 5,35 & Positive dynamics & $+0,33$ \\
\hline
\end{tabular}

Source: compiled by the authors.

The coefficients of significance in the blocks of indicators, used to assess the economic potential of the organization, are taken by the calculation of the component - priorities for the matrix of paired comparisons. Based on selected number of indicators, they are: for 
productive-innovative block $-0,27$; for financial block $-0,32$; for labor block $-0,27$; for marketing block $-0,14$.

If the calculation is performed by external users without access to all necessary information, the values of coefficients of significance in blocks of indicators can be changed. Hence, the transformation methods, depending on evaluated subject, are possible.

It is proposed to use the following scale for the resultant assessment of the economic potential of the organization: if $E P \geq 0,75$, the economic potential of the organization is high; if of $0.50 \leq E P \leq 0,74$, the economic potential of is medium; if $E P<0,50$, the economic potential is low.

The described method was tested on the example of PJSC "Dalryba" according to the financial accounts for 2016 (table 1).

The calculations have allowed to conclude that the level of economic potential of JSC "Dalryba" in 2016 was high (EP = 0,816).

Taking into account the results of the conducted research we can make the following conclusions:

1. The economic potential of the organization is a multiway category, that can be determined by combining the resource and resultative approaches (the most frequently used in modern science)

2. For effective implementation of the economic potential of the organization it is necessary to evaluate the already reached level and to reveal reserves for its increase.

3. Assessment of the economic potential of the organization should be based on a system-based approach and include evaluation of productive- innovative, financial, labor and marketing potentials of the organization. It is recommended to carry out calculation of integral index, that allows to take into account the recommended values, included in the formula of indicators and taking into consideration the industry features of the activities of a particular organization. The conducted testing (on the basis of accounting data of JSC "Dalryba") proves the viability of the proposed methodology.

\section{REFERENCES}

1. Chipovskaya I.S., Levchenko T.A. The formation of synergies in the operation of the fishery cluster. Ekonomika i predprinimatelstvo. 2015. No. 4-2 (57-2). Pp. 291-296.

2. Kanyuka Yu.G. Perfection of approaches to formation, development and use of marketing potential of the company in the new markets: the author's abstract of the dissertation of the candidate of economic sciences: 08.00.05. St. Petersburg, 2017. 20 p.

3. Konvisarova E.V., Neprokin A.V., Konvisarov A.G. The ways of improvement of financial state of small construction company. Vektor nauki Toliattinskogo gosudarstvennogo universiteta. Seriya: Ekonomika i upravleniye. 2016. No. 2 (25). Pp. 22-27.

4. Kovalev V.V. Corporate finance and accounting. Moscow: Prospekt, 2015. 916 p.

5. Krashennikova T.V. Management of the potential of the socio-economic system as a determinant of its sustainable development: the author's abstract of the dissertation of the candidate of economic sciences: 08.00.05. Rostov-na-Donu, 2016. 30 p.

6. Latkin A.P., Kravets A.V. The main problems of preservation and development of the labor potential of the Russian Primorye. Vektor nauki Toliattinskogo gosudarstvennogo universiteta. Seriya: Ekonomika i upravleniye. 2017. No 1 (28). Pp. 23-30.

7. Nadvornaya G.G., Klimchuk S.V., Oborin M.S., Gvarliani T.E. Theory and methodology for assessing the economic potential of enterprises. Ekonomicheskie i socialnye peremeny: fakty, tendentsii, prognoz. 2016. No 6. Pp. 70-90.

8. Starovoytov M.K., Fomin P.A. Features of the assessment of the potential of industrial enterprises. Antikrizisnoe i vneshnee upravlenie. 2006. No 2. Pp. 27-41.

9. Timofeeva Yu.V. Assessment of the economic potential of the organization: financial and investment potential. Ekonomicheskiy analiz: teoriya i praktika. 2009. № 1 (130). Pp. 4353.

10. Sheshukova T.G., Kolesen E.V. Improvement of the methodology for assessing the economic potential of an economic entity. Perm: Permskiy gosudarstvennyy nacionalnyy 
issledovatelskiy universitet, 2013. $196 \mathrm{p}$.

11. Vorozhbit O.Yu. Theoretical and methodological bases of management of competitiveness of entrepreneurial structures in the fishing industry: the author's abstract of the dissertation of the Doctor of Economic Sciences: 08.00.05. Vladivostok, 2009. 34 p.

12. Vorozhbit O.Yu., Shashlo N.V. Integration process and common agricultural market under the conditions of the Eurasian Economic Union // International Business Management. 2016. T. 10. №19. C. 4635-4643.

13. Vorozhbit O.Yu., Terenteva T.V., Titova N.Yu. Sustainable development of fishing complex in Primorsky krai via formation of territorial-sectoral industrial cluster. Azimut nauchnykh issledovaniy: ekonomika i upravleniye. 2016. T. 5. No. 2 (15). Pp. 53-57.

Zhigunova O.A. Methodology of analysis and forecasting of the economic potential of the enterprise: the dissertation of the Doctor of Economics: 08.00.12. Ekaterinburg, 2010. $339 \mathrm{p}$. 